Journal of Social Sciences 8 (1): 85-90, 2012

ISSN 1549-3652

(C) 2012 Science Publications

\title{
Religious Dogma without Religious Fundamentalism
}

\author{
Erik Daniel Baldwin \\ Department of Philosophy, Purdue University, Beering Hall, 100 N. University St \\ West Lafayette, IN 47907 and the Center for Philosophy of Religion, \\ The University of Notre Dame, 419 Malloy Hall, Notre Dame, IN 46556, USA
}

\begin{abstract}
Problem statement: New Atheists and Anti-Theists (such as Richard Dawkins, Daniel Dennett, Sam Harris, Christopher Hutchins) affirm that there is a strong connection between being a traditional theist and being a religious fundamentalist who advocates violence, terrorism, and war. They are especially critical of Islam. On the contrary, I argue that, when correctly understood, religious dogmatic belief, present in Judaism, Christianity, and Islam, is progressive and open to internal and external criticism and revision. Moreover, acknowledging that human knowledge is finite and that humans are fallible and have much to learn, dogmatic religious believers accept that they ought to value and seek to acquire moral and intellectual virtues, including the virtues of temperance and reasonability. Conclusion/Recommendations: While some Muslims advocate violence, terrorism, and war, others accept the concept of dogma articulated here and even speak out against the very things that Dawkins et al abhor. The contentious claims of the New Atheists and Anti-Theists to the contrary, therefore, while popular and rhetorically forceful, are false and do not withstand careful scrutiny.
\end{abstract}

Key words: Aristotle, atheism, dogmatism, fundamentalism, Islam, theism

\section{INTRODUCTION}

According to New Atheists and Anti-theists, including popular authors and critics such as Richard Dawkins, Daniel Dennett, Sam Harris, and Christopher Hutchins, dogmatic religious believers are doxastically irrational, unreasonable and imprudent. Accordingly, Jews, Christians and Muslims are blamed for social, economic and political conflicts and violence, oppression and war, in the Middle East and beyond. The basic idea is that these religious institutions inculcate irrational beliefs and overzealous attitudes, thereby causing believes to be deeply offended by people who reject their beliefs, which in turn leads to armed conflict and violence (Dawkins, 2006; Dennett, 2006; Whitehouse, 2009; Harris, 2004; 2011; Hutchins, 2008; Hourani, 1985).

While it is obvious that Judaism, Christianity and Islam have much in common, it is equally clear that the their core doctrinal claims about the nature and purposes of "the God of Abraham, Isaac and Jacob" are logically incompatible with one another: Muslims alone affirm that there is no God but Allah and that Mohammed is his prophet; only Christians affirm Jesus to be the incarnate Son of God sent to take away the sins of the world; only Jews rely exclusively on the Moses and the Prophets as the basis of their faith and practice. New Atheists and Anti-Theists, noting that their core religious beliefs are mutually inconsistent (with respect to truth), claim that Jews, Christians, and Muslims-in virtue of holding mutually inconsistent beliefs about God and his purposes-are highly predisposed towards violence, terrorism, and war, at least more so than those who lack traditional theistic beliefs. Essentially, their claim is that, by its very nature, dogmatic religious belief inculcates attitudes or character traits that make people more apt to be violent, terrorizing, and warlike. However, if we carefully scrutinize that claim in light of a historically accurate concept of dogma, and when we consider the fact that many believers accept this more accurate conception of dogmatic religious belief, we see that the nature and behavior of dogmatic religious believers is much different than New Atheists and Anti-Theists suppose.

To make my case, first I consider what Karl Barth and Adolf Harnack, two philosophically inclined 20th century Christian Theologians, have to say about the dogma and dogmatic religious belief. Skipping over many historical intermediaries, we look much further back in history in order to see how preeminent Christian and Islamic philosopher-theologians, influenced by Aristotle and Neo-Platonists, and in particular, Augustine, articulated and defended a similar St West Lafayette, IN 47907 and The Center for Philosophy of Religion, The University of Notre Dame, 419 Malloy Hall, Notre Dame, IN 46556, USA 
concept of dogma. Third, I show that many contemporary Muslims accept this concept of dogma, (or at least something very much like it). I do not have space to consider Judaism here separately, but similar conclusions hold. For example, see Cohn-Sherbok, (1996); Frank et al. (2000) and Frank et al. (1997).

Barth (1959), in his Dogmatics in Outline, writes:

The subject of dogmatics is the Christian Church ... as science dogmatics takes into account the content of proclamation in the Christian Church $(9,10)$

\section{He also writes that:}

Dogmatics is a science ... an attempt at comprehension and exposition, at investigation and instruction, which is related to a definite object and sphere of activity ... Christian dogmatics is an attempt-an attempt to understand and an attempt to expound, an attempt to see, to hear and to state definite facts, to survey and co-ordinate these facts, to present them in the form of a doctrine (9) (Barth, 1959)

Similarly, in Outlines of the History of Dogma (1893), Adolf Harnack (1851-1930) writes that religion is a practical affair that regards "our highest happiness". The Christian faith rests on divine revelation and makes objective, historical claims. Harnack writes that the desire to unify in our understanding what is known on the basis of revelation with historical and scientific knowledge (i.e., with objective truth claims that are known independently of revelation) leads to "the effort to verify these articles [of faith] with reference to science and to history". We do this because we desire a statement of faith that "will not be impaired by our wavering knowledge of nature and history". However, science and history are fallible. Given our cognitive limitations, it seems impossible to find indubitable foundations for articles of faith. Consequently, the science of dogmatics is never finished, but is continuously moving ever closer towards an unreachable limit line or an event horizon (Harnack, 2008).

Both Barth and Harnack affirm that the science of Christian dogmatics involves thinking and reflecting on that which is known on the basis of revelation together with that which is known by other means. As such, dogmatics is an unfolding, communal, and historically situated attempt at rightly articulating available sources of knowledge into Christian categories. Not all such attempts are equally successful. All attempts to systematize religious knowledge explicitly rely on God's help and grace, and so presuppose the possibility of error. This in turn suggests that Christians, and likeminded Muslims and Jews as well, recognize that dogmatic religious belief should be held in a spirit of moral and intellectual humility and that religiously dogmatic persons aim to be humble, teachable and open to correction. Thus, rather than naively assuming that they have "the truth, the whole truth and nothing but the truth", dogmatic believers participate in a corporative attempt to live out, in their intellectual lives and activities, Anselm's motto of 'faith seeking understanding". As a community, they embark on the century's long attempt to realize and acquire a deeper understanding of the articles of faith, in hopes of gaining a greater understanding of what they presently grasp only partially and incompletely.

Historically, preeminent and influential Jewish, Christian and Muslim philosophers and theologians have accepted this concept of dogma. One reason for this similarity is that, generally, contact and dialogue with Greek philosophy had a strong influence on the theological and philosophical development of all three of the main branches of the Abrahamic faith tradition. As a case in point, consider how Aristotelian ideas of the nature of practical reason and moral and intellectual virtue contributed to the articulation of the concept of religious dogma at issue. In particular, given the aims of this study, we focus on the Islamic tradition.

Islamic philosophy begins with al-Kindi (801-866) and al-Farabi (870-950). Both of them were highly influenced by encounters with Greek philosophy. Their commentaries and original works contributed to the formation of Neo-Platonism, a harmonious composite of (primarily) various strands of Aristotle, Plato and Plotinus (McGinnis and Reisman, 2007).

McGinnis and Reisman (2007) write that al-Kindi adopted:

... a general Aristotelian scientific outlook on the cosmos, with such concepts as the act/potency, form/matter and substance/accident distinctions and the four causes. One also finds strains of Neoplatonism in his discussion of the "One" and the "many" in On First Philosophy, his most important philosophical work (McGinnis and Reisman, 2007)

Similarly, al-Farabi wrote commentaries on Aristotle and his philosophy and original works in which he presented "his own syncretistic philosophical system”. Specifically, al-Farabi: 
... synthesizes an Aristotelian metaphysics of causation with a highly developed Neoplatonic emanationist scheme that incorporates the Ptolemaic planetary system. $\mathrm{He}$ in turn integrates a sophisticated theory of the intellect into this metaphysical framework (McGinnis and Reisman, 2007)

Islamic theologians, the mutakallimun, and in particular the Mu'tazila, influenced by al-Kindi and alFarabi, also made use of Greek philosophical resources. Mu'tazila mutakallimun affirm that the universe is rationally explicable and knowable, that it behaves "according to known patterns of events ... on which human reasoning is based (Martin et al., 1997)". Naturally, the Mu'tazila articulated and defended "Rationalistic" epistemic principles, which in turn informed their views on the principles of Islamic jurisprudence and hermeneutics. In contrast, "Traditionalists" were critical of what they perceived to be the improper or excessive foreign and external influence of the Greeks on Islamic theology. Their disagreement centered on what properly warrants the rational acceptance of the truth-claims of Islam. Both accepted the authority of the Qur'an, the Sunna (the sayings of the Prophet) and the Hadith (reports about the Prophets actions) and the principles of communal and scholarly consensus (ijma) and reasoning by analogy (qiyas), first proposed by the Jurists of Islamic law (or Sharia). But only the Mu'tazila affirmed that human reason (aql) is able to determine the correct interpretation of Qur'anic passages and Hadith. Naturally, the Mu'tazila added aql to this list of proper warrants and the Traditionalists did not. Accordingly, Mu'tazila affirmed that reason alone (aql) is able to prove or demonstrate that God cannot lie to or deceive humans, reveals that the moral goodness or badness of an act or event is not arbitrary but something that is 'in the event itself', is able to demonstrate the existence of God and supports the view that because humans are free agents that are morally responsible for their actions. Traditionalists affirmed that such things are known not on the basis of unaided human reason, but revolution.

As one might expect, the Mu'tazila accepted a broadly Aristotelian account of theoretical and practical reason, including the importance of intellectual and moral virtues. Aristotle maintained that the proper end of human activity is happiness (eudemonia in Greek), which consists in "activity of the soul in accordance with virtue (Aristotle, 1999)". Virtue is concerned with feelings and actions and so "the business of virtue" is to seek pleasurable experiences and avoid (unnecessary and non-instrumentally good) painful ones and to have and express feelings such as anger, sadness and the like, "at the right time, about the right things, towards the right people, for the right end and in the right way (Aristotle, 1999)". Note that it would be incorrect to say that Traditionalists rejected these views. Rather, they would say whatever reasons for accepting Aristotelian views must be grounded in revelation, and not reason (aql).

Of course, many Islamic philosophers did not accept all of Aristotle's views. For instance, many of them did not accept Aristotle's view that the universe is eternal and affirmed uniquely theological virtues. And some affirmed that Aristotelian views needed to be corrected by or understood in the light of revelation. Others-including al-Kindi, al-Farabi, and the Mu'tazilaaffirmed that a proper reading of the Quran must take Aristotelian views into consideration and that a generally Aristotelian account of human nature and moral and intellectual virtue is true but consistent with the truths of Islam.

Apparently, al-Kindi, al-Farabi and the Mu'tazila were motivated by epistemological concerns sufficiently similar in kind to those of Barth and Harnack. Thus, we may say that early Islamic philosophers and the Mu'tazila sought to 'think together' Greek philosophy and Islamic revelation and thereby engaged in an attempt "at comprehension and exposition, at investigation and instruction" and made "an attempt to see, to hear and to state definite facts, to survey and co-ordinate these facts". We might even say that Islamic philosophers were Augustinians of a sort with respect to their philosophical methodology.

Augustine affirmed that all things belong to God. Allegorically interpreting passages in Exodus 3:22 and 11:2 regarding the taking of "jewels of silver and jewels of gold and raiment" from the Egyptians, he argued in support of the Christian right to select truth from Greek thought without accepting its errors (Chadwick, 1992). In effect and in their own way, early Islamic philosophers exercised their own right to take these truths and see them in light of Islam. Peter Adamson expresses a similar view. He writes:

Al-Kindi argues that Greek thought is to be welcomed, despite its foreign province, because our own inquiry into the truth is greatly assisted by those who have achieved it in the past (Adamson and Taylor, 2005)

The project of balancing the knowledge claims of theology with historical and scientific truth and knowledge claims is taking place in the contemporary Islamic religious tradition. In my conclusion, I defend this claim, elaborate on its implications and significance. 


\section{CONCLUSION}

First, let us note that contemporary Islamic thinkers advocate the Islamization of knowledge. According to Ibrahim Ragab, to Islamize the theory of knowledge is, "to recast knowledge as Islam relates to it, i.e., to redefine and reorder the data, to re-evaluate the conclusions, to reproject the goals and to do so in such a way so as to make the disciplines enrich the vision and serve the cause of Islam (Ragab, 1998)". Is Islamization so construed compatible with a Barthian/Augustinian account of dogma? Does it involve an Aristotelian account of virtue? Probably not, one might object, adding that Islamization is, probably, merely a mark of Religious Fundamentalism and Radicalism.

However, in response, note that Ragab argues that an Islamic view of the social sciences of anthropology, sociology, psychology and philosophy, ought to be coupled with a factually correct and modernized Islamic worldview. Reminiscent of the Mu'tazilla, Ragab advocates a "sensible integration" of what is known by means of science, reason and revelation into an over-arching, syncretistic theory and in so doing incorporate all valid sources of knowledge and unify them under Islamic categories of thought (Ragab, 1998). So stated, Ragab's proposal seems similar in kind to Alvin Plantinga's defense of Augustinian Science.

Plantinga writes that Augustine (354-430) held that every human is either a citizen of the City of God (Civitas Die) or the City of World (Civitas Mundi). These two cities are fundamentally opposed to one another, thus wholly neutral or 'secular' inquiry is just not possible. He writes:

... the Christian community ought to think about the subject matter of the various sciences - again, in particular the human sciences (i.e., economics, psychology, sociology, political science, parts of sociobiology), but also to some degree the so-called natural sciences - from an explicitly theistic or Christian point of view (Plantinga, 1996)

Note that Augustinian Science is dogmatic in the Barthian and Harnackian sense. Ragab's description of Islamization seems to be dogmatic in just this sense. Now, it is implausible to think that Plantinga's notion of Augustinian Science inexorably leads to or somehow necessitates or entails radicalism or violent fundamentalism. But, then, on account of the relevant similarities, it seems equally incorrect to draw these conclusions about Ragab's concept of Islamization. That is, denying any neutral starting point prior to inquiry, and so starting with the core beliefs of one's religious tradition, even though they are in conflict with the core beliefs of others, in no way implies or entails religious Radicalism or Fundamentalism, let alone an inordinate proclivity towards violence, terrorism, and war.

More troubling, however, is the objection that Radicalism and Fundamentalism are essential features or characteristics of Islam. If violence is an intrinsic feature of Islam, then there is no such thing as Moderate Islam. On this view, Islam simply is Radical Islam. So Sam Harris writes, "Let us now acknowledge the obvious: There is a direct link between the doctrine of Islam and Muslim violence (Whitehouse, 2009)". In a similar tone, Dawkins writes that, "To fill a world with religion, or religions of the Abrahamic kind, is like littering the streets with loaded guns" and says that "'radicalised Britons' and 'extremists' are just honest Muslims who take their scriptures seriously". Sam Harris adds that, "the basic thrust of [Islamic] doctrine is undeniable: Convert, subjugate, or kill unbelievers; kill apostates and conquer the world (Whitehouse, 2009)". Robert Spencer (2005) makes similar claims in his The Politically Incorrect Guide to Islam. However, all of them seem to overlook or downplay the fact that but there are voices in the Muslim community defending what some have called Moderate, Progressive, or Liberal Islam, too.

Consider a few representative voices of so-called Liberal Islam first. Although they tend to be condemned by some Muslims as heretics "by consensus", according to their own selfunderstanding, they are genuine Muslims advocating reform within Islam. The Ahle Qur'an (the Qur'an Only) movement argues that the Qur'an is the only genuine record of revelation from Allah and argues that the Hadith should not be given the authoritative weight they now have. Similarly, the Bazm-e-Tolu-eIslam movement aims "to remove all non-Quranic ideologies, beliefs and practices prevalent in presentday Islam and replace them with Quranic concepts based upon reason and rationale (http://www.toluislam.com)". Note that (Rashad, 2000; Rab, 2008) defend similar views.

Consider Moderate and Progressive Islam as one category. Work by contemporary Islamic philosophers calls for a renewal of Mu'tazili Rationalism. Mohammed Arkoun argues for this conclusion from a PostStructuralist perspective; Fatima Mernissi offers a critique of "Traditionalism" and a defense of rational communicative discourse, democracy and dialogue; Fazlur Rahman argues for revival and reform in Islam; Hassan Hanafi calls for a renewal of Kalam (Martin et al., 1997). Al-Jarabi (1999) calls attention to the shortcomings of Traditionalism and defends a modern, 
Averroist philosophy. Muhammad Shahrur offers "a comprehensive attempt to reconcile the religion of Islam with modern philosophy as well as the rational worldview of the natural sciences" and argues that "the religious inheritance of Islam must be critically read and interpreted anew (2009)". Several Islamic web pages, including Free-Minds.org, Progressivemuslims.org, ijtihad.org, and islamicreform.org, are devoted to spreading the same core message: the need for reform within Islam. These and other voices within the Islamic community speak out against violence, terrorism and jihad. For instance, Imam Abdul Jalil Sajid said:

I watched with shock and horror the tragic events unfolding in America on Tuesday the 11th September 2001. It was unbelievable to witness such a dreadful, wanton evil act of senseless murder. The killing of innocent people cannot be justified. I condemned this crime against humanity

It seems right to say that Liberal, Moderate and Progressive Muslims, like al-Kindi and al-Farabi and the Mu'tazili, are heavily informed by Aristotelian views of virtue. Unpacking this view, we can draw out an important consequence, namely, that like any other types of human activity, violence and war are not to be taken lightly. If violent activities are to be engaged in, they must be done in accord with virtue. That is, warlike or violent activity, if engaged in at all, must be "at the right time, about the right things, towards the right people, for the right end and in the right way (Aristotle, 1999)".

The conception of religious dogma at issue here is not overly irrational or prone to violence and war. And, if contemporary Liberal, Moderate and Progressive Muslims are right, the noxious elements of Radical Islam are neither necessary nor essential features of Islamic religious dogmatic belief. Rather, the concept of religious dogma at issue here, articulated and defended by the likes of Barth and Harnack, Augustine and Plantinga, and al-Kindi, al-Farabi, and Ragab is incompatible with the Radicalism and Fundamentalism. We can generalize our findings. Many contemporary philosophers and theologians in the various Abrahamic religious traditions accept genuine religious dogmatism, and so set out to cultivate the moral and intellectual virtues and character traits it requires. Accordingly, dogmatic religious believers actually stand with the New Atheists and Anti-Theists when the cry out against violence, terrorism, and war. A greater awareness of this fact and a more complete account of the development of the conception of dogmatic religious belief articulated here are in order.
(Thanks to Benjamin Craig for his helpful response, and to participants and audience members at the 12th Annual Building Bridges Conference at Southern Illinois University Carbondale for their comments. Special thanks to Aisha Raees for organizing the conference and Charity Anderson for comments on an even earlier version.)

\section{REFERENCES}

Adamson, P. and R.C Taylor, 2005. The Cambridge Companion to Arabic Philosophy. 1st Edn., Cambridge University Press, Cambridge, ISBN-10: 052152069X pp: 448.

Al-Jarabi, M., 1999. Arab-Islamic Philosophy. 1st Edn., University of Texas Press, Austin, ISBN: 9780292704800 pp: 152.

Aristotle, 1999. Nicomachean Ethics. 1st Edn., Amazon Media EU, Hackett Publishing Company, ISBN: 0872204642 pp: 391.

Barth, K. 1959. Dogmatics in Outline. 1st Edn., Harper and Brothers, New York, pp: 155.

Chadwick, H., 1992. Augustine, Confessions. 1st Edn., Oxford University Press, Oxford, pp: 123.

Cohn-Sherbok, Dan, 1996. Medieval Jewish Philosophy: An Introduction. 1st Edn., Routledge, ISBN-10: 0700704140 pp: 126.

Dawkins, R., 2006. The God Delusion. 1st Edn., United Kingdom, Bantam Books, ISBN-10: 0-618-680004 pp: 406.

Dennett, D.C., 2006. Breaking the Spell: Religion as a Natural Phenomenon. 1st Edn., Allen Lane, London, ISBN-10: 0713997893 pp: 448.

Frank, D.H., O. Leaman, and C.H. Manekin, 2000. The Jewish Philosophy Reader. 1st Edn., Routledge, London, ISBN-10: 0415168597 pp: 618.

Frank, D.H. and O. Leaman, 1997. History of Jewish Philosophy. 1st Edn., Routledge, London, ISBN 0415080649 pp: 934.

Harnack, A.V., 2008. Outlines of the History of Dogma. 1st Edn., Read Books, ISBN-10: 1409769933 pp: 576.

Whitehouse, B., 2009. Sam Harris and the End of Faith: a Muslim's Critical Response. 1st Edn., Bilquees Press, ISBN-10: 9781441453464 pp: 180.

Harris, S., 2011. Letter to a Christian Nation. 1st Edn., Transworld, New York, ISBN-10: 1446464903 pp: 112.

Harris, S., 2004. The End of Faith: Religion, Terror, the Future of Reason. 1st Edn., Norton, New York, ISBN-10: 0393327655 pp: 348.

Hourani, G., 1985. Reason and Tradition in Islamic Ethics. 1st Edn., Cambridge University Press, Cambridge, ISBN-10: 0521035635 pp: 300. 
Hutchins, C., 2008. God is not Great: How Religion Poisons Everything. 1st Edn., Allen and Unwin, Crows Nest, ISBN-10: 9781741755725 pp: 384.

Rashad, K., 2000. Quran, Hadith, and Islam. 1st Edn., Freemont, California, Universal Unity. ISBN-10: 1881893049 pp: 89.

Martin, R.C., M.R. Woodward and S.D. Atmaja, 1997. Defenders of Reason in Islam: Mu? Tazilism from Medieval School to Modern Symbol. 1st Edn., Oneworld. Oxford, pp: 251.

McGinnis, J. and D.C. Reisman, 2007. Classical Arabic Philosophy: An Anthology of Sources. 1st Edn., Hackett Indianapolis, ISBN-10: 9780872208711 pp: 427.
Plantinga, Alvin, 1996. Science: Augustinian or Duhemian? Faith Philosophy, 13: 369369.

Rab, A., 2008. Exploring Islam in a New Light: An Understanding from the Quranic Perspective.

Ragab, I.A., 1998. On the methodology of the islamization of the social sciences. Proceeding of the International Conference on Islamization of Sociology and Anthropology, (ISA' 98), International Islamic University, Malaysia.

Spencer, R., 2005. The Politically Incorrect Guide to Islam (and the Crusades). 1st Edn., Regnery Pub, Washington, ISBN-10: 0895260131 pp: 270. 